BENTHM OPEN
CrossMark
Content list available at: www.benthamopen.com/TOASJ/
DOI: $10.2174 / 1874331501812010194,2018,12,194-206$

RESEARCH ARTICLE

\title{
Influence of Nitrogen and Phosphorus Application on Bulb Yield and Yield Components of Onion (Allium Cepa L.)
}

Negasi Tekeste ${ }^{1, *}$, Nigussie Dechassa ${ }^{2}$, Kebede Woldetsadik ${ }^{2}$, Lemma Dessalegne ${ }^{3}$ and Abuhay Takele $^{3}$

${ }^{1}$ Aksum University, College of Agriculture, P O Box 314, Shire, Ethiopia

${ }^{2}$ Department of Plant Sciences, Haramaya University, P O Box 138, Dire-Dawa, Ethiopia

${ }^{3}$ Melkassa Agricultural Research Centre, P O Box 2500, Adama, Ethiopia

Received: October 5, 2017

Revised: February 10, 2018

Accepted: March 27, 2018

Abstract:

\section{Introduction:}

Onion is an important cash crop for smallholder farmers in the Central Rift Valley of Ethiopia. However, the yield of the crop is low owing to a number of constraints out of which soil nutrient depletion and inappropriate soil fertility management practices are the most important ones.

\section{Methods and Materials:}

A field experiment was carried out for two consecutive years of 2011 and 2012 using irrigation at Melkassa, Central Rift Valley Region of Ethiopia, to assess the response of onion to different levels of nitrogen and phosphorus fertilizers and to identify economical rates of the fertilizers for optimizing the yield and quality of the crop. The treatments consisted of five levels of nitrogen $\left(0,34.5,69,103.5\right.$ and $\left.138 \mathrm{~kg} \mathrm{ha}^{-1}\right)$ and four levels of phosphorus $\left(0,46,92\right.$, and $\left.138 \mathrm{~kg} \mathrm{P}_{2} \mathrm{O}_{5} \mathrm{ha}^{-1}\right)$. The experiment was carried out as a randomized complete block design in a factorial arrangement with three replications.

\section{Results:}

The results of the study revealed that the main effect of nitrogen significantly $(\mathrm{P} \leq 0.05)$ affected most of the growth parameters and bulb characters which all attained maximum values at $138 \mathrm{~kg} \mathrm{~N} \mathrm{ha}^{-1}$. The main effect of $\mathrm{P}$ significantly $(\mathrm{P} \leq 0.05)$ influenced leaf number, leaf length, and bulb diameter. Nitrogen and phosphorus interacted to influence total and marketable bulb yields. Application of $\mathrm{N}$ at the rate of $103.5 \mathrm{~kg} \mathrm{~N} \mathrm{ha}{ }^{-1}$ combined with $138 \mathrm{~kg} \mathrm{ha}^{-1} \mathrm{P}_{2} \mathrm{O}_{5}$ led to the production of the highest total and marketable bulb yield of onion. However, results of the economic analysis revealed that application of $\mathrm{N}$ at the rate of $103.5 \mathrm{~kg}$ ha ${ }^{-1}$ and $\mathrm{P}_{2} \mathrm{O}_{5}$ at $92 \mathrm{~kg} \mathrm{ha}^{-1}$ led to the highest net return.

Keywords: Fertilization, Inorganic, Nitrogen, Onion, Phosphorus, Yield.

\section{INTRODUCTION}

Onion (Allium cepa. L.) is one of the most important vegetables grown in Ethiopia. As a bulb crop, it is mainly produced by smallholder farmers as a source of cash income and for flavouring the local stew 'wot' [1, 2]. A significant proportion of onion produced in Ethiopia is obtained from the Central Rift Valley region, which is mainly attributed to availability of irrigation potential and proximity to market [3].

The productivity of onion bulbs in Ethiopia, including the Central Rift Valley area, is low with the national average

* Address correspondence to this author at the Aksum University, College of Agriculture, P O Box 314, Shire, Ethiopia, Tel: ???; E-mail: negasite@gmail.com 
yield of $10.75 \mathrm{t} \mathrm{ha}^{-1}$ [4] as compared to the world's average yield of $17.30 \mathrm{tha}^{-1}$ [5]. However, the potential productivity could go far beyond the current national average yield with proper management practices. Reports indicated that vegetable production in Ethiopia is constrained mainly by, among others, depleting soil fertility and poor agronomic practices such as unbalanced/improper fertilization [6, 2]. Accordingly, research gaps on agronomy of onion crop have been reported in Ethiopia in general and central rift-Valley region in particular [1].

Reference [7] suggested that maintaining soil fertility in Ethiopia is impossible unless appropriate farming system is adopted and inorganic fertilizers are used. Besides, reference [8] indicated that soil physical and chemical characteristics are the most influential factors for growth, yield, and quality of Alliums'. In the Central Rift Valley (CRV) region, for maintaining soil fertility and for the sake of higher bulb yields, growers apply higher amount of inorganic nitrogen and phosphorus than the regional blanket recommendations. Most smallholder onion farmers apply rates much higher than the ones commonly recommended by the research system which amounts to $69 \mathrm{~kg} \mathrm{~N} \mathrm{ha}^{-1}$ and 92 $\mathrm{kg} \mathrm{P}_{2} \mathrm{O}_{5} \mathrm{ha}^{-1}$. However, some other farmers under-supply the nutrients to the crop. In both cases, yield and quality of the crop are compromised. Excess application of inorganic nitrogen and phosphorus fertilizers makes luxuriant growth with little effect on yield and causing bulb decays $[9,10]$.

Deficiencies of nitrogen and phosphorus are widespread in all sub-Saharan Africa including Ethiopia [11, 12]. Onions are more susceptible to nutrient deficiencies than most other crop plants because of their shallow and unbranched root system; hence they require and often respond well to addition of fertilizers [13]. Uptake levels of nutrients by onion crops may vary from less than $50 \mathrm{~kg}$ to more than $300 \mathrm{~kg} \mathrm{~N}$ ha ${ }^{-1}$, depending on cultivar, climate, plant density, fertilization and yield levels $[14,15]$. Supplying an optimum nitrogen level was proved to be very essential for plant growth and production of high yield as well as improving the quality of onion bulbs [16 - 18]. In Ethiopia [19, 20], reported increased shallot and onion bulb yields with $\mathrm{N}$ application in the range of $75-150$ and $69 \mathrm{~kg} \mathrm{ha}^{-1}$, respectively. On a sandy loam soil in a semi-arid Rift Valley region of Ethiopia, irrigated onion plants also benefited from application of 90-120 kg ha- $\mathrm{N}$ compared to unfertilized crops [21]

Comparative studies of nutrient requirement of vegetables have shown that onion requires higher level of available $\mathrm{P}$ content to achieve maximum yield than most other temperate vegetables [22]. Phosphorus deficiencies in onions reduce root and leaf growth, bulb size, and yield and also delay maturation [13]. Many authors reported that phosphorus application rates of up to $200 \mathrm{~kg} \mathrm{P}$ ha maximized onion yields and bulb weights [23 - 25]. Increased P levels are also known to improve bulb size and the number of marketable bulbs in shallots [26, 27]. Similarly, in Ethiopia [28], indicated that phosphorus fertilization at the rates of 25 or $50 \mathrm{~kg} \mathrm{ha}^{-1}$ increased yield and bulb weight of shallots even when soil analysis did not show deficiency of the nutrient. However, differing results were reported that $\mathrm{P}$ application did not significantly influence yield of onions [20].

Reference [29] suggested efficient and economical use of fertilizer because the input constitutes a substantial proportion of the total cost of growing vegetables. Hence, economic feasibility of fertilizer practices is an essential element in improving crop productivity. Therefore, farmers would adopt only improved practices which are more paying. Therefore, owing to the heavy feeding nature of nutrients by the crop as well as due to soil nutrient depletion under the intensive irrigated cropping system in the study area, judicious application of fertilizers is imperative to sustain and enhance onion production and productivity. However, little information is available on the response of the popular Bombay red onion variety to varied rates of the fertilizers in terms of bulb yield, which is important to optimize fertilizer application for enhanced productivity and quality of the crop. This paper presents the results of a study conducted to investigate the response of the onion to varied levels of mineral nitrogen and phosphorus fertilizers in the Central Rift Valley Region of Ethiopia.

\section{MATERIALS AND METHODS}

\subsection{Description of the Study Area}

The experiment was conducted at Melkassa Agricultural Research Centre, during the 2011 and 2012 season using irrigation. The Centre is situated in the Central Rift Valley of Region of Ethiopia with latitude of $8^{\circ} 24^{\prime}$ N and longitude of $39^{\circ} 21^{\prime}$ E at the elevation of 1550 metres above sea level. The area has an average annual rainfall of $768 \mathrm{~mm}$, which is erratic and uneven in distribution. The site has a mean maximum temperature of $28.5^{\circ} \mathrm{C}$ and mean minimum temperature of $12.6^{\circ} \mathrm{C}$. The soils of the research area are classified as Phallic Andosol with a characteristic feature of deep pumice or volcanic [30]. The total annual rainfall during the growing period of the experiment was $810.1 \mathrm{~mm}$ and 
$924.7 \mathrm{~mm}$ during 2010/2011 and 2011/2012, respectively. The mean monthly minimum and maximum temperatures were $9.0^{\circ} \mathrm{C}$ and $28.8^{\circ} \mathrm{C}$ during the 2011 cropping season and 13.3 and $28.9^{\circ} \mathrm{C}$ during the 2012 cropping season.

\subsection{Treatments and Experimental Design}

The treatments consisted of five nitrogen rates $\left(0,34.5,69,103.5\right.$ and $\left.138 \mathrm{~kg} \mathrm{ha}^{-1}\right)$ and four phosphorus rates $(0,46$, 92, and $\left.138 \mathrm{~kg} \mathrm{P}_{2} \mathrm{O}_{5} \mathrm{ha}^{-1}\right)$. The experiment was laid out as a randomized complete block design in a factorial arrangement and replicated three times per treatment. Urea $(46 \% \mathrm{~N})$ and Triple Superphosphate $\left(46 \% \mathrm{P}_{2} \mathrm{O}_{5}\right)$ were used as a source of nitrogen and phosphorus, respectively. Urea was applied in two splits, with one half at planting and the remaining half side-dressed 45 days after transplanting. The full dose of phosphorus was applied at the time of planting.

\subsection{Planting and Agronomic Practices}

An onion variety named Bombay Red, which is the most widely cultivated variety in the region, was used for the study. Seeds were sown in a nursery bed on a well-prepared seed bed. Seedlings were transplanted to the experimental field 50 days after sowing when they attained a 3 to 4 leaf stage. Planting was done on ridges of about $25 \mathrm{~cm}$ high, adopting the recommended spacing of $40 \mathrm{~cm}$ between furrows, $20 \mathrm{~cm}$ between rows on the ridge, and $5 \mathrm{~cm}$ between plants. The plot size was $3.6 \mathrm{~m} \mathrm{x} 2.0 \mathrm{~m}$ and a total of 80 plants were planted per double row. Each experimental plot had six rows and a distance of $1.0 \mathrm{~m}$ was maintained between plots and $1.5 \mathrm{~m}$ between blocks. Transplanting was done at start of January 2011 and 2012 and harvesting was carried out at mid April 2011 and 2012 during both years. All cultural practices were employed as per the recommendations by [1].

\subsection{Soil Sampling and Analysis}

Before planting, composite soil samples were collected from rooting depth of the crop. The collected soil samples were analysed for different soil physico-chemical properties. Determination of soil particle size distribution was carried out using the hydrometer method according to [31]. Soil $\mathrm{pH}$ was measured potentiometrically using a digital a $\mathrm{pH}$ meter in 1:2.5 soil to solution ratio with $\mathrm{H}_{2} \mathrm{O}$. Organic carbon was determined following the wet digestion method as described by [32]. Total $\mathrm{N}$ was determined by the Kjeldahl procedure as described by [33]. Available P in the soil samples was determined using the Olsen method [34]. Exchangeable cations were extracted with 1.0 M-ammonium acetate at $\mathrm{pH} 7$ and were measured by the atomic adsorption spectrophotometer.

\subsection{Data Collection and Measurement}

Data were collected and measurements were carried out on the following growth parameters and bulb characters at physiological maturity and harvesting. Plant height was measured from the soil surface to the top of the longest mature leaf. Leaf number per plant was measured by counting the total number of leaves of ten randomly taken plants from each plot and averaging it. The length of the longest leaf was measured with a metre scale from the base to the apex. Leaf diameter was determined by measuring the central width of each leaf of ten randomly sampled plants from each plot and taking the average. Neck thickness was measured at the narrowest point using a vernier caliper. Leaf area index was recorded by dividing the average leaf area per plant to ground area, where leaf area was measured using portable leaf area meter Model CI-202.

Bulb length and diameter were measured centrally from ten randomly taken bulbs from each plot using a vernier caliper, and averaged. Bulb weight was determined by weighing ten bulbs and calculating the average. Total dry biomass yield was recorded as the weight of ten randomly taken dried bulbs, above ground parts and roots at the time of maturity. Drying was performed at the temperature of $70^{\circ} \mathrm{C}$ in an oven until a constant weight was attained. Dry weights of bulb were determined by taking ten bulbs and chopping them into small $1-2 \mathrm{~cm}$ cubes, and then mixing them thoroughly. Two sub-samples each weighing $200 \mathrm{~g}$ was weighed. The exact weight of each sub-sample was determined and recorded as fresh weight. Each sub-sample was placed in a paper bag and put in an oven until a constant dry weight was attained. Each sub-sample was immediately weighed and recorded as dry weight. Harvest index was calculated as the ratio of dry bulb weight to the total dry biomass yield per plant.

The following parameters were recorded at the appropriate growth stages and computed as the mean of individual plots. Bolter plants per plot were determined by counting as the number of plants producing flower stalks and expressed in percentage in relation to the total number of plants. Days to physiological maturity were determined as the actual number of days from transplanting to the date on which the leaves of more than $80 \%$ of the plants in each plot senesced. Total bulb yield was computed based on the weight of matured fresh bulb yield per plot and calculated on a hectare 
basis in tonnes. Marketable bulb yield was determined after discarding bulbs smaller than $20 \mathrm{~g}$ in weight as well split, thick necked, rotten, and dis-coloured bulbs [1]. Split bulb percentage was determined by counting the number of split bulbs per plot and expressing in percentage in reference to the total number of normal bulbs per plot.

\subsection{Economic Evaluation}

The economic evaluation comprising partial budget with dominance, and marginal rate of return was carried out. To estimate economic parameters, the marketable bulb yield was valued based on average market price collected from the local markets during two consecutive years of production where dry onion bulb was 8 Birr per $\mathrm{kg}$. The average cost of urea and DAP were 7.50 and 9.5 Birr per kg respectively. A wage rate of 25.0 Birr per man-day was considered.

Some of the concepts used in the partial budget analysis are gross field benefit (GFB), total variable cost (TVC) and the net benefit (NB). The GFB ha ${ }^{-1}$ was obtained as the products of real price and the mean onion bulb yield for each treatment. TVC refers to the sum of all costs of variable inputs (fertilizers) and management practices whereas the NB $\mathrm{ha}^{-1}$ is the difference between the GFB and the TVC [35].

The dominance analysis procedure, which was used to select potentially profitable treatments, comprised ranking of treatments in an ascending order of TVC from the lowest to the highest cost to eliminate treatments costing more but producing a lower NB than the next lowest costing treatment. The selected and rejected treatments by using this technique were referred to as undominated and dominated treatments, respectively. For each pair of ranked undominated treatments, a percentage marginal rate of return (\% MRR) was calculated. The percent MRR between any pair of undominated treatments denoted the return per unit of investment in crop management practices expressed as percentage. The MRR (\%) was calculated as follows [35].

For a treatment to be considered a worthwhile option to farmers, the marginal rate of return (MRR) needed to be at least between 50 and $100 \%$ [35]. Thus, the minimum acceptable rate of return was considered to be $50 \%$.

\subsection{Statistical Analysis}

Data were subjected to analysis of variance using SAS (Statistical Analysis System, version 9.1, Copyright 2003, SAS institute Inc.USA). The analysis was conducted on combined data of the two years. Mean separation was done using Fisher's LSD. Economic analysis was carried out according to the economic manual of [35].

\section{RESULTS AND DISCUSSION}

\subsection{Soil Analysis}

The results of the soil analysis before fertilizer application indicated that soils of the study site is dominantly sandy loam with organic carbon content of $1.5 \%$, total nitrogen content of $0.12 \%$ which are low according [36, 37]. The available phosphorus content of the soil is $5.10 \mathrm{ppm}$ Table (1), which is low according to [38]. The low organic carbon as well as total nitrogen contents could possibly be due to continuous cultivation through removal of crop residues for other competing ends such as feed and fuel wood and lack of incorporation of organic materials into the soils as suggested by [39-41]. The $\mathrm{pH}$ of the soil is neutral in reaction having a value of 6.68 , which is optimal for the growth of onion crop [13]. The exchangeable bases are optimal for crop production; with high and medium ranges [42].

Table 1. Physico-chemical properties of the soil before the experiment.

\begin{tabular}{|c|c|}
\hline Soil Properties & Composition \\
\hline Sand (\%) & 50 \\
\hline Silt(\%) & 21 \\
\hline Clay (\%) & 29 \\
\hline Texture & Sandy loam \\
\hline $\mathrm{P}^{\mathrm{H}}(1: 2.5)$ & 6.68 \\
\hline $\mathrm{OC}(\%)$ & 1.50 \\
\hline $\mathrm{TN}(\%)$ & 0.12 \\
\hline Avail P $(\mathrm{ppm})$ & 5.10 \\
\hline $\mathrm{Na}$ & 0.75 \\
\hline $\mathrm{Ca}$ & 20.6 \\
\hline
\end{tabular}


(Table 1) contd.....

\begin{tabular}{|c|c|}
\hline Soil Properties & Composition \\
\hline $\mathrm{K}$ & 1.93 \\
\hline $\mathrm{Mg}$ & 4.70 \\
\hline
\end{tabular}

\subsection{Growth Parameters, Bolting and Physiological Maturity}

The main effect of nitrogen significantly $(P \leq 0.05)$ increased plant height while $\mathrm{P}$ and its interaction with $\mathrm{N}$ did not Table (2). Increasing the rate of nitrogen from nil to 34.5 and $69 \mathrm{~kg} \mathrm{~N} \mathrm{ha}^{-1}$ increased plant height by 26 and $30 \%$, respectively. The heights of plants grown at these two rates of the nutrient were in statistical parity. However, when the rate of nitrogen was increased from 69 to 103.5 and $138 \mathrm{~kg} \mathrm{~N} \mathrm{ha}^{-1}$, plant height increased further significantly. Increasing the rate of nitrogen from 103.5 to $138 \mathrm{~kg} \mathrm{~N}^{-1}$ tended to decrease plant height. Thus, the tallest plants grew in the treatment that received $103.5 \mathrm{~kg} \mathrm{~N}^{-1} \mathrm{a}^{-1}$ whereas the shortest plants were obtained from nil application of the nutrient Table (2). The average height of plants grown at the rate of $103.5 \mathrm{~kg} \mathrm{~N}^{-1}$ exceeded the average height of plants grown at nil application by an additional $39 \%$.

Table 2. Effect of $\mathrm{N}$ and $\mathrm{P}$ on bolting, days to physiological maturity and growth parameter of on.

\begin{tabular}{|c|c|c|c|c|c|c|c|}
\hline $\mathbf{N}\left(\mathbf{k g ~ h a}^{-1}\right)$ & $\begin{array}{c}\text { Bolting } \\
(\%)\end{array}$ & DPM & \begin{tabular}{|c|} 
Plant height \\
(cm)
\end{tabular} & Leaf number per plant & \begin{tabular}{|c|} 
Leaf length \\
$(\mathrm{cm})$
\end{tabular} & $\begin{array}{c}\text { Leaf Diameter } \\
(\mathrm{cm})\end{array}$ & LAI \\
\hline 0 & $2.50 \mathrm{a}$ & 99.92d & $49.03 \mathrm{~d}$ & $8.00 \mathrm{~d}$ & $45.75 \mathrm{~d}$ & $0.97 \mathrm{c}$ & $2.77 \mathrm{c}$ \\
\hline 34.5 & $2.41 \mathrm{a}$ & $100.46 \mathrm{c}$ & $61.82 \mathrm{c}$ & $9.33 \mathrm{c}$ & $49.07 \mathrm{c}$ & $1.06 \mathrm{c}$ & $3.23 \mathrm{c}$ \\
\hline 69 & $2.39 \mathrm{ab}$ & $101.67 \mathrm{c}$ & $64.03 \mathrm{bc}$ & $9.92 \mathrm{c}$ & $50.52 \mathrm{abc}$ & $1.23 \mathrm{~b}$ & $3.93 b$ \\
\hline 103.5 & $2.36 \mathrm{~b}$ & $102.92 b$ & $68.01 \mathrm{a}$ & $10.62 b$ & $52.13 \mathrm{ab}$ & $1.27 \mathrm{ab}$ & $3.99 \mathrm{ab}$ \\
\hline 138 & $2.30 \mathrm{~b}$ & $104.29 \mathrm{a}$ & $66.37 \mathrm{ab}$ & $12.33 \mathrm{a}$ & $53.81 \mathrm{a}$ & $1.35 \mathrm{a}$ & $4.39 \mathrm{a}$ \\
\hline LSD & 0.123 & 1.233 & 3.021 & 0.605 & 2.453 & 0.107 & 0.456 \\
\hline F-test & $*$ & $* * *$ & $* * *$ & $* * *$ & $* * *$ & $* * *$ & $* * *$ \\
\hline \multicolumn{8}{|l|}{$\mathrm{P}_{2} \mathrm{O}_{5}\left(\mathrm{~kg} \mathrm{ha}^{-1}\right)$} \\
\hline 0 & 2.37 & 101.73 & 60.23 & $9.30 \mathrm{c}$ & $48.61 \mathrm{~b}$ & 1.16 & 3.48 \\
\hline 46 & 2.39 & 101.17 & 62.59 & $9.93 \mathrm{~b}$ & $50.57 \mathrm{ab}$ & 1.15 & 3.59 \\
\hline 92 & 2.40 & 102.03 & 61.87 & $10.27 \mathrm{ab}$ & $50.08 \mathrm{ab}$ & 1.18 & 3.71 \\
\hline 138 & 2.40 & 102.21 & 62.71 & $10.67 \mathrm{a}$ & $51.77 \mathrm{a}$ & 1.23 & 3.86 \\
\hline LSD & 0.110 & 1.103 & 2.702 & 0.541 & 2.194 & 0.096 & 0.408 \\
\hline F-test & NS & NS & NS & $* * *$ & $*$ & NS & NS \\
\hline CV (\%) & 9.0 & 2.1 & 8.50 & 10.5 & 8.4 & 16.0 & 21.0 \\
\hline
\end{tabular}

Means with the same letter within a column are statistically non-significant at $\mathrm{P} \leq 0.05$ according to Fishers' LSD, NS=non-significant, DPM=Days to physiological maturity, LAI=Leaf area index

The increase in plant height in response to the increased application of nitrogen may be attributed to the increment in vegetative growth parameters which could probably be due to the important role of nitrogen in plant photosynthesis by improving leaf area index and chlorophyll contents thus resulting in higher photosynthetic rate and higher vegetative growth [43]. In line with the present study, it has been reported that maximum plant height of onion at maximum $\mathrm{N}$ rates of $120 \mathrm{~kg} \mathrm{ha}^{-1} \mathrm{~N}$ [44]. Phosphorus application did not affect plant height. In line with the findings of this study, reference [20] reported the absence of significant differences in plant height of onion plants due to application of different rates of phosphorus on vertisoles of central Ethiopian highlands.

The main effects of both nitrogen and phosphorus fertilizer significantly $(P \leq 0.001)$ enhanced the number of leaves produced per plant (Table 2). Increasing the rate of nitrogen from nil to 34.5, 69, 103.5, and $138 \mathrm{~kg} \mathrm{~N} \mathrm{ha}^{-1}$ enhanced leaf number per plant by additional values of $17,24,33$, and $54 \%$, in the order mentioned here.

The increased number of leaves due to the increase in $\mathrm{N}$ application could be attributed to the role nitrogen plays in enhancing biochemical processes, which in turn enhance vegetative growth. Reference [45] stated that $\mathrm{N}$ is a constituent of many fundamental cell components and it plays a vital role in all living tissues of the plant and no other element has such an effect on promoting vigorous plant growth. Accordingly [46], indicated that nitrogen is an essential element for onion growth through build-up of protoplasm and proteins, which induce cell division and meristematic activities. Consistent to the findings of this study, Reference [47] revealed increased number of leaves with increasing rates of N, with the maximum values up to $150 \mathrm{~kg} \mathrm{ha}^{-1}$ and $200 \mathrm{~kg} \mathrm{ha}^{-1}$ in onion and garlic, respectively. 
Increasing the rates of phosphate from 0 to 46,92 and $138 \mathrm{~kg} \mathrm{P}_{2} \mathrm{O}_{5}$ ha $^{-1}$ increased leaf number significantly by 7.0 , 10, and 15\%, respectively. However, the leaf numbers per plant obtained from plants grown at 46 and $92 \mathrm{~kg} \mathrm{P}_{2} \mathrm{O}_{5}$ ha ${ }^{-1}$ and that obtained from 92 and $138 \mathrm{~kg} \mathrm{P}_{2} \mathrm{O}_{5} \mathrm{ha}^{-1}$ were in statistical parity Table (2). The maximum leaf number was obtained from plants grown at $138 \mathrm{~kg} \mathrm{P}_{2} \mathrm{O}_{5} \mathrm{ha}^{-1}$ whilst the minimum was obtained from those grown at nil application of phosphate. The increase in leaf number in response to the increased application of phosphate may be attributed to the role phosphorus plays in root growth and development and formation of phosphoproteins and phospho-lipids that encourage meristematic activity of plants, resulting in increased number of leaves per plant [48]. In line with the findings of the study, References [49, 20] reported significant increases in the number of leaves of onions due to increased application of $\mathrm{P}$.

Nitrogen and phosphorus significantly affected leaf length of onion plants. However, there was no significant interaction effect of $\mathrm{N}$ and $\mathrm{P}$ on leaf length (Table 2). The highest leaf length was recorded at the highest $\mathrm{N}$ rate of 138 $\mathrm{kg} \mathrm{ha}^{-1}$, which, however, did not differ statistically from that at $103.5 \mathrm{~kg} \mathrm{~N} \mathrm{ha}^{-1}$. The positive effect of $\mathrm{N}$ on leaf length may be due to its role on chlorophyll, enzymes, and proteins syntheses. Reference [45] indicated that $\mathrm{N}$ is the major constituent of proteins and the presence of abundant protein tends to increase the size of the leaves and ultimately increase carbohydrate synthesis. In conformity to the present study, reference [44] reported significant increases in leaf length and diameter of onion with increases in $\mathrm{N}$ up to $150 \mathrm{~kg} \mathrm{ha}^{-1}$ and $200 \mathrm{~kg} \mathrm{ha}^{-1}$, respectively.

With respect to phosphorus application, the longest leaves were obtained in response to the application of $138 \mathrm{~kg}$ $\mathrm{P}_{2} \mathrm{O}_{5} \mathrm{ha}^{-1}$. However, the leaf length value obtained at this rate of was in statistical parity with that obtained in response to the applying 46 and $92 \mathrm{~kg} \mathrm{P}_{2} \mathrm{O}_{5}$ ha $^{-1}$. The shortest leaf was recorded for the control treatment (Table 2). The increase in leaf number in response to the increased application of phosphate may be attributed to the growth-promoting effect of the nutrient. In line with the findings of this study [50], reported an increased leaf length of onion plants with increasing rates of phosphorus.

Nitrogen fertilization significantly $(P \leq 0.001)$ affected leaf diameter of onion plants. However, phosphorus application and its interaction with nitrogen did not (Table 3.2). The highest leaf diameter was observed at $138 \mathrm{~kg} \mathrm{~N}$ $\mathrm{ha}^{-1}$, while the lowest leaf diameter was recorded for plants grown at the control treatment. There was about $39 \%$ increment in leaf diameter at $138 \mathrm{~kg} \mathrm{~N} \mathrm{ha}^{-1}$ compared to the control treatment (Table 2).

The present findings are also in accord with those of $[44,51]$, who reported highest values of vegetative growth parameters of onion at the highest rates of nitrogen application. P application did not significantly affect leaf diameter, which is in line with the findings of [20] on vertisoles of central highlands of Ethiopia.

The leaf area index (LAI) of onion was significantly $(P \leq 0.001)$ affected by application of different doses of nitrogen. However, phosphorus fertilization and its interaction with $\mathrm{N}$ did not affect this parameter Table (2). Although there was no significant difference with $\mathrm{N}$ at $103.5 \mathrm{~kg} \mathrm{ha}^{-1}, \mathrm{~N}$ at $138 \mathrm{~kg} \mathrm{ha}^{-1}$ resulted in a maximum leaf area index of 4.39. The minimum (2.77) was obtained at the control which was in statistical parity with $\mathrm{N}$ at $34.5 \mathrm{~kg} \mathrm{ha}^{-1} \mathrm{Table}^{(2)}$. This might be due to the fact that nitrogen is an integral component of many essential plant compounds like chlorophyll, proteins and amino acids promotes carbohydrate synthesis through photosynthesis and ultimately increase vegetative growth of plants [52]. Similarly, reported that increasing the nitrogen application rate remarkably enhanced LAI expansion rate in Persian shallot, and maximum LAI was obtained at the highest dose of $300 \mathrm{~kg} \mathrm{ha}^{-1}$.

Increasing the rate of nitrogen from nil to 34.5 and $69 \mathrm{~kg} \mathrm{~N} \mathrm{ha}^{-1}$ did not affect bolting percentage. However, increasing the rate of nitrogen from 0 to 103.5 and $138 \mathrm{~kg} \mathrm{~N} \mathrm{ha}^{-1}$ significantly decreased bolting percentage by 5.6 to $8 \%$, respectively.

The results of this study also indicated that nitrogen application prolonged the days required to reach physiological maturity by the crop Table (2). When the rate of nitrogen was increased from 0 to $34.5,69,103.5$, and $138 \mathrm{~kg} \mathrm{~N} \mathrm{ha}^{-1}$, the duration in days required to reach physiological maturity increased by $0.5,1.7,3$, and $4.4 \%$ in the order listed here (Table 2).

\subsection{Bulb Characters}

Nitrogen and phosphorus fertilization and their interaction did not significantly $(P \leq 0.05)$ affect the formation of thick-necked bulbs Table (3). This could be due to the minimal direct effect of fertilization in the formation of thicknecked bulbs. In agreement with this suggestion, Brewster (2008) reported that neck-thickness is a physiological disorder that is influenced by seasons, sites and cultivars, not by fertility. 
Table 3. Effect of $\mathbf{N}$ and $P$ on neck thickness, split bulb, bulb length, bulb diameter, and mean bulb weight of onion.

\begin{tabular}{|c|c|c|c|c|c|}
\hline $\begin{array}{c}\text { Nitrogen } \\
\left(\mathrm{kg} \mathrm{ha}^{-1}\right)\end{array}$ & Neck thickness (cm) & $\begin{array}{l}\text { Split bulbs } \\
\text { (\%) }\end{array}$ & $\begin{array}{l}\text { Bulb diameter } \\
(\mathrm{cm})\end{array}$ & $\begin{array}{l}\text { Bulb length } \\
\text { (cm) }\end{array}$ & Average bulb weight(g) \\
\hline 0 & 1.02 & $1.88(1.37)$ & $4.52 \mathrm{c}$ & $6.09 \mathrm{~b}$ & $105.84 \mathrm{c}$ \\
\hline 34.5 & 1.09 & $2.02(1.42)$ & $4.93 \mathrm{~b}$ & $6.24 \mathrm{~b}$ & $109.10 \mathrm{bc}$ \\
\hline 69 & 1.16 & $2.07(1.44)$ & $5.45 \mathrm{a}$ & $6.58 \mathrm{a}$ & $114.93 a$ \\
\hline 103.5 & 1.16 & $2.25(1.50)$ & $5.45 \mathrm{a}$ & $6.84 \mathrm{a}$ & $120.00 \mathrm{ab}$ \\
\hline 138 & 1.12 & $2.46(1.57)$ & $5.67 \mathrm{a}$ & $6.82 \mathrm{a}$ & $119.78 \mathrm{a}$ \\
\hline LSD & 0.143 & 0.018 & 0.237 & 0.256 & 8.323 \\
\hline F-test & NS & NS & $* * *$ & $* * *$ & $* * *$ \\
\hline \multicolumn{6}{|l|}{$\mathrm{P}_{2} \mathrm{O}_{5}\left(\mathrm{~kg} \mathrm{ha}^{-1}\right)$} \\
\hline 0 & 1.12 & $1.93(1.39)$ & $4.75 \mathrm{c}$ & 6.58 & 113.38 \\
\hline 46 & 1.09 & $2.04(1.43)$ & $5.11 \mathrm{~b}$ & 6.51 & 114.86 \\
\hline 92 & 1.11 & $2.16(1.47)$ & $5.32 \mathrm{~b}$ & 6.41 & 111.87 \\
\hline 138 & 1.10 & $2.37(1.54)$ & $5.64 \mathrm{a}$ & 6.56 & 115.60 \\
\hline F-test & NS & NS & $* * *$ & NS & NS \\
\hline LSD & 0.128 & 0.016 & 0.212 & 0.229 & 7.444 \\
\hline $\mathrm{CV}(\%)$ & 22.7 & 22 & 8.01 & 6.7 & 12.8 \\
\hline
\end{tabular}

Means with the same letter within a column are statistically non-significant at $\mathrm{P} \leq 0.05$ according to Fisher's LSD; NS=non-significant, the numbers in parenthesis are square root-transformed.

The formation of split bulbs was not significantly $(P \leq 0.05)$ influenced by $\mathrm{N}, \mathrm{P}$ fertilization and their interaction Table (3). Consistent with the results of this study, $[53,13]$ indicated that bulb splitting is under genetic control, where growth in high temperatures and short days increases lateral shoot production.

It has been shown in Table (3) that nitrogen fertilization highly significantly $(P \leq 0.001)$ affected bulb length and diameter, while $\mathrm{P}$ fertilization only significantly affected bulb diameter. The interaction of $\mathrm{N}$ and $\mathrm{P}$ did not significantly affect both bulb length and diameter Table (3). The highest bulb diameter and length were observed at $\mathrm{N}$ rates of 138 and $103.5 \mathrm{~kg} \mathrm{ha}^{-1}$, respectively whilst the lowest bulb length and diameter were recorded at the control treatment, which were in statistical parity with bulb length recorded at the rate of $34.5 \mathrm{~kg} \mathrm{~N}^{-1}$ (Table 3 ).

$\mathrm{N}$ fertilization at the rate of $138 \mathrm{~kg} \mathrm{ha}^{-1}$ increased bulb diameter by almost $25 \%$ in comparison to the bulb diameter obtained in the control treatment. This may be linked to the increase in dry matter production and its allocation to the bulb. The maximum bulb length recorded at $103.5 \mathrm{~kg} \mathrm{~N}^{-1}$ was $12 \%$ higher than the bulb length obtained in the control treatment Table (3). In agreement with this finding [54 - 56], reported a significant increase in bulb diameter of onion with increase in nitrogen fertilization. Consistent with the results of this study [55 - 58], also reported increased onion bulb lengths in response to nitrogen application.

Bulb diameter was significantly $(P \leq 0.001)$ affected by phosphorus fertilization. The maximum bulb diameter was recorded in response to the application of $138 \mathrm{~kg} \mathrm{P}_{2} \mathrm{O}_{5} \mathrm{ha}^{-1}$, showing about $19 \%$ increment over the control treatment Table (3). In accord with this result, phosphorus fertilization at $60 \mathrm{~kg} \mathrm{ha}^{-1}$ significantly increased onion bulb diameter $[59,49]$. The positive effect of $\mathrm{P}$ on bulb diameter could be attributed to its influence on partitioning assimilates to bulb development as suggested by [59].

Average bulb weight was significantly $(P \leq 0.001)$ affected by nitrogen but not by phosphorus fertilization and its interaction with $\mathrm{N}$ Table (3). The highest bulb weight was recorded in response to the application of $103.5 \mathrm{~kg} \mathrm{~N} \mathrm{ha}^{-1}$, which was in statistical parity with the bulb weight obtained at 69 and $138 \mathrm{~kg} \mathrm{~N} \mathrm{ha}^{-1}$ whilst the lowest was obtained in the control treatment. There was a $13 \%$ increment in bulb weight at $103.5 \mathrm{~kg} \mathrm{~N} \mathrm{ha}^{-1}$ in comparison with the control treatment Table (3). In conformity with these findings [59, 60], reported increased bulb weights of onions and shallots with increase in nitrogen application in Ethiopia, respectively. Moreover [56], reported similar findings. The increased bulb weight with $\mathrm{N}$ fertilization in the current study could be attributed to the increase in plant height, number of leaves produced, leaf length, and extended physiological maturity, which may have increased assimilate production and allocation to the bulbs.

\subsection{Total and marketable bulb yields}

There were significant $(P \leq 0.001)$ interaction effects of nitrogen and phosphorus fertilization on total and 
marketable bulb yields of onion Table (4). The highest total bulb yield was obtained in response to the application of $103.5 \mathrm{~kg} \mathrm{~N} \mathrm{ha}^{-1}$ combined with $138 \mathrm{~kg} \mathrm{P}_{2} \mathrm{O}_{5} \mathrm{ha}^{-1}$. However, the bulb yields obtained at these rates of the two combined fertilizers were in statistical parity with the total bulb yields obtained at $138 \mathrm{~kg} \mathrm{P}_{2} \mathrm{O}_{5}$ ha $^{-1}$ combined with $138 \mathrm{~kg} \mathrm{~N}^{-1}$ and $92 \mathrm{~kg} \mathrm{P}_{2} \mathrm{O}_{5}$, and combined with 103.5 and $138 \mathrm{~kg} \mathrm{~N} \mathrm{ha}^{-1}$. The lowest total and marketable bulb yields were recorded at $0 \mathrm{~kg} \mathrm{~N}$ and $\mathrm{P}_{2} \mathrm{O}_{5}$ ha $^{-1}$ Table (4). Thus, the maximum total bulb yield obtained in response to the combined application of $103.5 \mathrm{~kg} \mathrm{~N} \mathrm{ha}^{-1}$ and $138 \mathrm{~kg} \mathrm{P}_{2} \mathrm{O}_{5} \mathrm{ha}^{-1}$ exceeded the minimum total bulb yield obtained at nil application of the two fertilizers by about $53 \%$. This increase was $57.4 \%$ for marketable bulb yield at the same combined rates of the two fertilizers. Increasing the rate of $\mathrm{N}$ up to $103.5 \mathrm{~kg} \mathrm{ha}^{-1}$ combined with all doses of $\mathrm{P}_{2} \mathrm{O}_{5}$ led to increased production of total and marketable bulb yield.

Table 4. Effect of $\mathrm{N}$ and $\mathrm{P}$ fertilization on total and marketable bulb yield of onion.

\begin{tabular}{|c|c|c|c|c|}
\hline \multirow{3}{*}{$\begin{array}{c}\text { Fertilizer levels } \\
\mathbf{N}\left(\mathrm{kg} \mathrm{ha}^{-1}\right) \\
\end{array}$} & \multicolumn{4}{|c|}{ Total Yield $\left(\mathrm{t} \mathrm{ha}^{-1}\right)$} \\
\hline & \multicolumn{4}{|c|}{$\mathrm{P}_{2} \mathrm{O}_{5}\left(\mathrm{~kg} \mathrm{ha}^{-1}\right)$} \\
\hline & $\mathbf{0}$ & 46 & 92 & 138 \\
\hline 0 & $24.80 \mathrm{k}$ & $25.95 \mathrm{ijk}$ & $27.96 \mathrm{ghi}$ & $25.30 \mathrm{jk}$ \\
\hline 34.5 & 26.73hijk & $29.10 \mathrm{fgh}$ & $29.46 \mathrm{fg}$ & $28.64 \mathrm{gh}$ \\
\hline 69 & 27.84ghij & 31.38def & $29.71 \mathrm{efg}$ & $34.35 \mathrm{bc}$ \\
\hline 103.5 & $29.51 \mathrm{fg}$ & $32.73 \mathrm{~cd}$ & $35.61 \mathrm{ab}$ & $37.94 a$ \\
\hline 138 & $31.50 \mathrm{def}$ & $32.19 \mathrm{cde}$ & $35.86 \mathrm{ab}$ & $37.82 \mathrm{a}$ \\
\hline F-test & \multicolumn{4}{|c|}{$* * *$} \\
\hline LSD & \multicolumn{4}{|c|}{2.632} \\
\hline \multirow[t]{3}{*}{ CV (\%) } & \multicolumn{4}{|c|}{7.4} \\
\hline & \multicolumn{4}{|c|}{ Marketable yield $\left(\mathrm{t} \mathrm{ha}^{-1}\right)$} \\
\hline & \multicolumn{4}{|c|}{$\mathrm{P}_{2} \mathrm{O}_{5}\left(\mathrm{~kg} \mathrm{ha}^{-1}\right)$} \\
\hline $\mathrm{N}\left(\mathrm{kg} \mathrm{ha}^{-1}\right)$ & 0 & 46 & 92 & 138 \\
\hline 0 & $21.98 \mathrm{k}$ & $23.83 \mathrm{jk}$ & 26.84 fghi & $22.83 \mathrm{~K}$ \\
\hline 34.5 & $24.43 \mathrm{ijk}$ & $26.65 \mathrm{ghi}$ & 26.12ghij & 25.61hij \\
\hline 69 & $24.48 \mathrm{ijk}$ & $28.22 \mathrm{efgh}$ & $28.08 \mathrm{efgh}$ & $31.15 \mathrm{bcd}$ \\
\hline 103.5 & $24.97 \mathrm{cdef}$ & $29.65 \mathrm{cde}$ & $32.24 \mathrm{abc}$ & $34.60 \mathrm{a}$ \\
\hline 138 & 28.69defg & 27.65 efgh & $32.09 \mathrm{abc}$ & $33.06 \mathrm{ab}$ \\
\hline F-test & \multicolumn{4}{|c|}{$* * *$} \\
\hline LSD & \multicolumn{4}{|c|}{2.772} \\
\hline CV (\%) & \multicolumn{4}{|c|}{8.6} \\
\hline
\end{tabular}

Means with the same letter within a column are statistically non-significant at $\mathrm{P} \leq 0.05$ according to Fisher's LSD.

In conformity with the results of this study [61], reported a significant interaction effect of nitrogen and phosphorus on bulb yield of onion [62]. similarly reported a significant increase in marketable bulb yield of onion with the combined application of 100:50:50 NPK kg ha ${ }^{-1}$ and $160 \mathrm{~N}, 60 \mathrm{P}_{2} \mathrm{O}_{5}$ and $80 \mathrm{~K}_{2} \mathrm{O} \mathrm{kg} \mathrm{ha}{ }^{-1}$, respectively. However, absence of significant interaction effect of nitrogen and phosphorus on bulb yield of onion was reported in central Rift Valley Region of Ethiopia [63]. This significant $\mathrm{N}$ and $\mathrm{P}$ interaction observed in the current study might be attributed to the effect of phosphate fertilizers in increasing use efficiency of nitrogen fertilizer as suggested by [64].

\subsection{Dry Bulb Yield, Total Dry Biomass, and Harvest Index}

Nitrogen fertilization significantly $(P \leq 0.001)$ affected both bulb dry weight and total dry biomass yield of onion while it did not significantly affect harvest index. Moreover, $\mathrm{P}$ and its interaction with $\mathrm{N}$ did not significantly affect all parameters considered Table (5). Bulb dry weight and total dry biomass yield increased by about $15 \%$ and $14 \%$ at 103.5 $\mathrm{kg} \mathrm{N} \mathrm{ha}{ }^{-1}$ over the checks, respectively. These characters showed a tendency to increase with the increase in $\mathrm{N}$ up to 138 $\mathrm{kg} \mathrm{ha}^{-1}$. However, further increases in $\mathrm{N}$ supply beyond $103.5 \mathrm{~kg} \mathrm{ha}^{-1}$ did not affect the characters Table (5). In line with this finding, nitrogen at the concentration up to $5,000 \mathrm{mg} \cdot \mathrm{L}^{-1}$ increased bulb fresh and dry weights [65]. The observed improvement in bulb dry weight as well as total dry biomass yield could be attributed to increased photosynthetic area in response to $\mathrm{N}$ fertilization that may have enhanced assimilate production and partitioning to the bulbs [66]. also reported a positive and significant correlation of leaf area index with total dry biomass and dry bulb yield of onion. 
Table 5. Effect of nitrogen and phosphorus fertilization on mean dry bulb yield, total dry biomass and harvest index of onion.

\begin{tabular}{|c|c|c|c|}
\hline $\begin{array}{c}\text { Fertilizer levels } \\
\left(\mathrm{Kg} \mathrm{ha}^{-1}\right) \\
\end{array}$ & $\begin{array}{c}\text { Dry bulb yield } \\
\text { per plant (g) }\end{array}$ & $\begin{array}{c}\text { Total dry biomass } \\
\text { per plant (g) }\end{array}$ & Harvest index \\
\hline \multicolumn{4}{|l|}{$\mathrm{N}$} \\
\hline 0 & $9.95 \mathrm{~b}$ & $13.96 \mathrm{c}$ & 0.70 \\
\hline 34.5 & $8.25 \mathrm{c}$ & $12.19 \mathrm{~d}$ & 0.69 \\
\hline 69 & $10.66 \mathrm{ab}$ & $15.38 \mathrm{~b}$ & 0.69 \\
\hline 103.5 & $11.48 \mathrm{a}$ & $15.91 \mathrm{ab}$ & 0.73 \\
\hline 138 & $11.40 \mathrm{a}$ & $16.53 \mathrm{a}$ & 0.72 \\
\hline F-test & $* * *$ & $* * *$ & NS \\
\hline LSD & 0.938 & 0.953 & 0.047 \\
\hline \multicolumn{4}{|l|}{$\mathrm{P}_{2} \mathrm{O}_{5}$} \\
\hline 0 & 10.50 & 14.71 & 0.72 \\
\hline 46 & 10.37 & 14.61 & 0.72 \\
\hline 92 & 10.15 & 14.76 & 0.69 \\
\hline 138 & 10.38 & 15.10 & 0.69 \\
\hline F-test & NS & NS & NS \\
\hline LSD & 0.839 & 0.852 & 0.042 \\
\hline CV (\%) & 15.9 & 11.3 & 11.8 \\
\hline
\end{tabular}

Means with the same letter within a column are statistically non-significant at $\mathrm{P} \leq 0.05$ according to Fisher's LSD, NS=non-significant

\subsection{Economic Analysis}

Partial budget with dominance for the fertilizer $\mathrm{N}$ and $\mathrm{P}$ is shown in Table (6). Dominance analysis revealed that

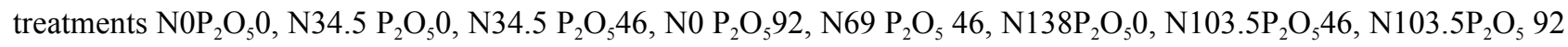
and $\mathrm{N} 103.5 \mathrm{P}_{2} \mathrm{O}_{5} 138$ were undominated. This indicated that increase in the total cost of the dominated treatments did not increase the net benefit proportionally; that means benefits were lower than the lowest total costs. Treatments without fertilizer $\mathrm{N}$ and $\mathrm{P}$ had lower total variable cost (TVC) when ranking treatments in order of increasing total cost. However, the highest net benefit was obtained with N103.5P138 resulting in the earning of 244491.75 Birr ha $^{-1}$.

Table 6. Partial budget with dominance.

\begin{tabular}{|c|c|c|c|c|c|c|c|c|c|}
\hline Treat & Yld(t ha $\left.{ }^{-1}\right)$ & $\operatorname{Ajy}\left(t^{h a} a^{-1}\right)$ & Urea(birr) & $\operatorname{TSP}\left(\mathrm{kg} \mathrm{ha}^{-1}\right)$ & Labour(birr) & TVC & $\operatorname{GFB}(\mathbf{A j Y})$ & NB & Dominance \\
\hline NOP0 & 21.98 & 19.97 & 0 & 0 & 0 & 0 & 158281.5 & 158281.50 & ND \\
\hline $\mathrm{N} 34.5 \mathrm{P} 0$ & 24.44 & 21.99 & 562.5 & 0 & 18.75 & 581 & 175934.25 & 175353.00 & $\mathrm{ND}$ \\
\hline N0P46 & 23.83 & 21.45 & 0 & 950 & 25 & 975 & 171607.50 & 170632.50 & $\mathrm{D}$ \\
\hline N69P0 & 24.48 & 22.04 & 1125 & 0 & 37.5 & 1163 & 176281.50 & 175119.00 & $\mathrm{D}$ \\
\hline $\mathrm{N} 34.5 \mathrm{P} 46$ & 26.65 & 23.99 & 562.5 & 950 & 43.75 & 1556 & \begin{tabular}{|l|}
191884.50 \\
\end{tabular} & 190328.25 & $\mathrm{ND}$ \\
\hline N103.5P0 & 24.97 & 22.47 & 1687.5 & 0 & 56.25 & 1744 & 179784.00 & 178040.25 & $\mathrm{D}$ \\
\hline N0P92 & 26.85 & 24.16 & 0 & 1900 & 50 & 1950 & \begin{tabular}{|l|l|}
193309.50 \\
\end{tabular} & 191359.50 & $\mathrm{ND}$ \\
\hline N69P46 & 28.22 & 25.40 & 1125 & 950 & 62.5 & 2138 & 203211.00 & 201073.50 & $\mathrm{ND}$ \\
\hline N138P0 & 28.70 & 25.83 & 2250 & 0 & 75 & 2325 & 206638.50 & 204313.50 & $\mathrm{ND}$ \\
\hline N34.5P92 & 26.13 & 23.51 & 562.5 & 1900 & 68.75 & 2531 & 188106.00 & 185574.75 & $\mathrm{D}$ \\
\hline N103.5P46 & 29.66 & 26.69 & 1687.5 & 950 & 81.25 & 2719 & 213540.38 & 210821.63 & $\mathrm{ND}$ \\
\hline N0P138 & 22.83 & 20.55 & 0 & 2850 & 75 & 2925 & 164408.25 & 161483.25 & $\mathrm{D}$ \\
\hline N69P92 & 28.08 & 25.27 & 1125 & 1900 & 87.5 & 3113 & 202185.00 & 199072.50 & $\mathrm{D}$ \\
\hline N138P46 & 27.65 & 24.89 & 2250 & 950 & 100 & 3300 & 199110.00 & 195810.00 & $\mathrm{D}$ \\
\hline N34.5P138 & 25.62 & 23.05 & 562.5 & 2850 & 94.02 & 3507 & 184434.00 & 180927.48 & $\mathrm{D}$ \\
\hline N103.5P92 & 32.25 & 29.02 & 1687.5 & 1900 & 106.25 & 3694 & 232197.00 & 228503.25 & $\mathrm{ND}$ \\
\hline N69P138 & 31.15 & 28.04 & 1125 & 2850 & 112.5 & 4088 & 224283.75 & 220196.25 & $\mathrm{D}$ \\
\hline N138P92 & 32.10 & 28.89 & 2250 & 1900 & 125 & 4275 & 231111.00 & 226836.00 & $\mathrm{D}$ \\
\hline N103.5P138 & 34.61 & 31.15 & 1687.5 & 2850 & 131.25 & 4669 & 249160.50 & 244491.75 & $\mathrm{ND}$ \\
\hline N138P138 & 33.06 & 29.75 & 2250 & 2850 & 150 & 5250 & 238034.25 & 232784.25 & $\mathrm{D}$ \\
\hline
\end{tabular}

The analysis of marginal rate of return, on the other hand, revealed that the return per unit cost of production was highest with $\mathrm{N} 69 \mathrm{P}_{2} \mathrm{O}_{5} 46$ followed by $\mathrm{N} 34.5 \mathrm{P}_{2} \mathrm{O}_{5} 0$ and $\mathrm{N} 103.5 \mathrm{P}_{2} \mathrm{O}_{5} 92$ having 5180.8, 2937.0 and 1813.5 Birr, 
respectively Table (7). This indicates that there was a rate of return of 518, 293.7 and 181.3 Birr for every Birr invested. All the undominated treatments resulted in a rate of return above the minimum acceptable rate of return (50-100\%) [35]. In this experiment, the highest marginal rate of return $(1813.5 \%)$ was obtained at the shift of treatment from N103.5 $\mathrm{P}_{2} \mathrm{O}_{5} 46$ to $\mathrm{N} 103.5 \mathrm{P}_{2} \mathrm{O}_{5} 92$ which resulted in a rate of return above 50\%. Therefore, treatment $\mathrm{N}_{103.5} \mathrm{P}_{2} \mathrm{O}_{5} 92$ had the highest marginal rate of return (1813.5\%) which is above the minimum required acceptable rate of return (Table 7).

Table 7. Marginal rate of return (MRR) and Sensitivity analysis to establish the profitability of onion to nitrogen and phosphorus.

\begin{tabular}{|c|c|c|c|c|c|c|c|c|c|}
\hline Treatment & $\begin{array}{c}\text { Ajy } \\
\text { (t/ha) }\end{array}$ & $\begin{array}{c}\text { Urea } \\
\text { (birr) }\end{array}$ & $\begin{array}{c}\text { TSP } \\
\text { (birr) }\end{array}$ & $\begin{array}{c}\text { Labor } \\
\text { (birr) }\end{array}$ & TVC & NB & C.TC & C.NB & MRR(\%) \\
\hline N0P0 & 19.97 & 0 & 0 & 0 & 0 & 158281.50 & & & \\
\hline N34.5P0 & 21.99 & 562.5 & 0 & 18.75 & 581 & 175353.00 & 581 & 17071.50 & 2937.0 \\
\hline N34.5P46 & 23.99 & 562.5 & 950 & 43.75 & 1556 & 190328.25 & 975 & 14975.25 & 1535.9 \\
\hline N0P92 & 24.16 & 0 & 1900 & 50 & 1950 & 191359.50 & 394 & 1031.25 & 261.9 \\
\hline N69P46 & 25.40 & 1125 & 950 & 62.5 & 2138 & 201073.50 & 188 & 9714.00 & 5180.8 \\
\hline N138P0 & 25.83 & 2250 & 0 & 75 & 2325 & 204313.50 & 188 & 3240.00 & 1728.0 \\
\hline N103.5P46 & 26.69 & 1687.5 & 950 & 81.25 & 2719 & 210821.63 & 394 & 6508.12 & 1652.9 \\
\hline N103.5P92 & 29.02 & 1687.5 & 1900 & 106.25 & 3694 & 228503.25 & 975 & 17681.63 & 1813.5 \\
\hline N103.5P138 & 31.15 & 1687.5 & 2850 & 131.25 & 4669 & 244491.75 & 975 & 15988.50 & 1639.8 \\
\hline
\end{tabular}

\section{CONCLUSION}

The findings of this study revealed that onion responded well to the application of nitrogen and phosphorus fertilizers. The two fertilizers interacted to influence the yield of the crop. Application of nitrogen at the rate of $103.5 \mathrm{~kg}$ $\mathrm{N} \mathrm{ha}^{-1}$ and phosphorus at the rate of $138 \mathrm{P}_{2} \mathrm{O}_{5} \mathrm{ha}^{-1}$ resulted in higher total and marketable bulb yields. However, these bulb yields were in statistical parity with the bulb yields obtained at 103.5 and $138 \mathrm{~kg} \mathrm{~N} \mathrm{ha}^{-1}$ and $92 \mathrm{~kg} \mathrm{P}_{2} \mathrm{O}_{5}$ ha $^{-1}$. This result shows that the optimum biological bulb yield of the crop was obtained at the combined application of $103.5 \mathrm{~kg} \mathrm{~N}$ $\mathrm{ha}^{-1}$ and $92 \mathrm{~kg} \mathrm{P}_{2} \mathrm{O}_{5} \mathrm{ha}^{-1}$. Moreover, based on economic analysis, the highest net benefit and economic returns were recorded at $103.5 \mathrm{~kg} \mathrm{~N} \mathrm{ha}^{-1}$ and $92 \mathrm{~kg} \mathrm{P}_{2} \mathrm{O}_{5}$ ha $^{-1}$. Therefore, nitrogen at the rate of $103.5 \mathrm{~kg} \mathrm{~N}^{-1}$ and phosphorus at the rate of $92 \mathrm{~kg} \mathrm{P}_{2} \mathrm{O}_{5} \mathrm{ha}^{-1}$ should be applied to enhance the productivity and economic benefit of Bombay Red onion variety in the in the study area. Further studies should be done over locations and growing seasons to find area-specific recommendation of the two fertilizers for onion production in the Central Rift Valley region of the country.

\section{ETHICS APPROVAL AND CONSENT TO PARTICIPATE}

Not applicable.

\section{HUMAN AND ANIMAL RIGHTS}

No animals/humans were used for studies that are the basis of this review.

\section{CONSENT FOR PUBLICATION}

Not applicable.

\section{CONFLICT OF INTEREST}

The authors declare no conflict of interest, financial or otherwise.

\section{ACKNOWLEDGEMENTS}

The research is part of my $\mathrm{PhD}$ work and the listed authors are my research advisory committee members. They have contributed from the inception of the research idea through its process of implementation and until its write up and completion of the work through the designing, analysis and editing of the research. The authors would like to acknowledge the Ethiopian ministry of education for the financial support of the work. Besides, Haramaya University is also acknowledged for facilitating the financial process. Moreover, Melkassa agricultural research center and the horticulture section of the research center are highly acknowledged for allowing using their research area and equipments for the research work and for encouraging support of its staff. 


\section{REFERENCES}

[1] Lemma D, Shimelis A. Onion Research results and experiences in dry bulb and seed production in Ethiopia. Vegetable Crops Improvement Research Ethiopian Agricultural Research Organization, Melkassa Agricultural Research Center 2003; 39.

[2] Fekadu M, Dandena G. Review of the status of vegetable crops production and marketing in Ethiopia. Uganda J of Agric Sci 2006; 12(2): 26-30.

[3] MOWR (Ministry of Water Resources). MOWR (Ministry of Water Resources) Awash River Basin Flood Control and Watershed Management Study Project, Phase-2 Summary Report, 2007; Vol-2 Annex-B, Addis Ababa, Ethiopia.

[4] Report on area and production of Private peasant holdings. 2010.

[5] FAO (Food and Agricultural Organization of the United Nations). FAOSTAT data, 2010 Available at 2010.www.FAO.org

[6] Pathak CS. Allium improvement in the tropics: Problems and AVRDC Strategy. Acta Hortic 1994; (358): $23-9$. [http://dx.doi.org/10.17660/ActaHortic.1994.358.2]

[7] Greenland DJ. Soil Fertility Management in support of Food Security in sub-Saharan Africa. FAO, 2001, Rome, p.55.

[8] Abbey L, Joyce DC. Water deficit stress and soil type effects on spring onion accumulation and partitioning in two potato cultivars. J Plant Nutr 2004; 25: 1621-30.

[9] Diaz-Perez JC, Purvis AC, Paulk JT. Bolting, yield, and bulb decay of sweet onion as affected by nitrogen fertilization. J Amer Soc H ort Sci 2003; 128: 144-9.

[10] Lee J, Jaegi S, Sunyoung L. Excessive Fertilization is Detrimental to Yield and Quality for Onion Grown on High Organic Matter Content Paddy Soils. Int J Veg Sci 2012; 18(3): 235-44. [http://dx.doi.org/10.1080/19315260.2011.623147]

[11] Mamo T, Erkossa T, Balesh T. In: Proc of the International Workshop on Teff Genetics and Improvement. In: Soil fertility and plant nutrition research on teff in Ethiopia; Debre Zeit, Ethiopia. 2001; pp. October 16-19; 18(3): 191-200.

[12] CIAT(International Center for Tropical Agriculture). Integrated Plant Nutrient Management in the Tropics: TSBF-CIAT's Achievements and Reflections 2002-2005. Colombia.: CIAT Publication No. 350. CIAT 2006; p. 101.

[13] Brewster JL. Onions and other vegetable Alliums, CABI International Vol. UK: II, Biddles Ltd, King’s Lynn 2008; p. 455. [http://dx.doi.org/10.1079/9781845933999.0000]

[14] Salo T. Effect of band placement and nitrogen rate on dry matter accumulation, yield and nitrogen uptake of cabbage, carrot and onion. Agric and Food Sci in Finland 1999; 8: 157-232.

[15] Pire R, Ramirez H, Riera J, de Gómez TN. Removal of N, P, K and Ca by an onion crop (Allium cepa L.) in a silty-clay soil, in a semiarid region of Venezuela. Acta Hortic 2001; (555): 103-9. [http://dx.doi.org/10.17660/ActaHortic.2001.555.12]

[16] Balemi T, Pal N, Saxena AK. Response of onion (Allium cepa L.) to combined application of biological and chemical nitrogenous fertilizers. Acta Agric Slov 2007; 89(1): 107-14.

[http://dx.doi.org/10.2478/v10014-007-0013-y]

[17] Biesiada A, Kolota E. The effect of nitrogen fertilization on yield and nutritional value of onion grown from sets for early cropping. Veg Crops Res Bulletin 2009; 70: 145-51.

[18] Shaheen AM, Fatma A. Rizk, Hoda A.M. Habib M. Abd El-Baky M.H. Nitrogen soil dressing and foliar spraying by sugar and amino acids as affected the growth, yield and its quality of onion plant. J Am Sci 2010; 6(8): 420-7.

[19] Kebede W, Gretsson U, Ascard J. Shallot yield, quality and storability as affected by irrigation and Nitrogen. J Hortic Sci Biotechnol 2003; 78(4): 549-53. a [http://dx.doi.org/10.1080/14620316.2003.11511661]

[20] Abdissa Y, Tekalegn T, Pant LM. Growth, bulb yield and quality of onion (Allium cepa L.) as influenced by nitrogen and phosphorus fertilization on Vertisol I. growth attribute biomass production and bulb yield. Afr J Agric Res 2011; 6(14): $3252-8$.

[21] Shimeles A. Onion research and production in Ethiopia. Acta Hortic 1997; (433): 95-7.

[22] Greenwood DJ, Cleaver TJ, Turner MK, Hunt J, Niendorf KB, Loquens SMH. Comparison of the effect of phosphate fertilizer on the yield, phosphate content and quality of 22 different vegetable and agricultural crops. J Agric Sci 1980; 95: 457-69. [http://dx.doi.org/10.1017/S0021859600039502]

[23] El-Rehim GHA. Effect of phosphorus fertilization on yield and quality of onion bulb under Egypt condition. Assiut J of Agri Sci 2000; 31 : $115-21$

[24] Singh RB, Singh SB. Significance of nitrogen, phosphorus and potassium on onion (Allium cepa L.) raised from onion sets (bulblets). Veg Sci 2000; 27: 88-9.

[25] Singh RP, Jam NK, Poonia BL. Response of Kharif onion to nitrogen, phosphorus and potash in eastern plains of Rajasthan. Indian J Agric Sci 2000; 70: 871-2

[26] Zaharah A, Vimala P, Zainab RS, Salbiah H. Response of onion and shallot to organic fertilizer on bris (rudua series) soil in Malaysia. Acta Hortic 1994; (358): 429-33. 
[http://dx.doi.org/10.17660/ActaHortic.1994.358.70]

[27] Nagaraju R, Haripriva K, Rajalingam GV, Sriamachandrasekarn V, Mohideen MK. Effect of VAM on growth and yield of aggregatum onion (Allium cepa L. var. aggregatum Don). South Indian Hortic 2000; 48: 40-5.

[28] Kebede W. Shallot (Allium cepa var.ascalonicum) responses to nutrients and soil moisture in sub humid tropical climate. PhD Thesis. Agraria: Swedish university of agricultural sciences 2003; 367.

[29] Greenwood DJ. The Fertilizer Society. Fertilizer requirements of vegetable crops. Proc. 145th, 1974 . London.; p.30.

[30] Kindie T, Walker S. Matching of Crop and Environment for optimal water use the case of Ethiopia. Phys Chem Earth 2004; 29 : 1061-7. [http://dx.doi.org/10.1016/j.pce.2004.09.024]

[31] Day PR. Hydrometer Method of Particle Size Analysis American Society of Agronomy, No 9, part II. USA: Madison, Winscosin 1965; pp. $562-3$.

[32] Walkley A, Black CA. An examination of the Degtjareff method for determining soil organic matter and a proposed modification of the chromic acid titration method. Soil Sci 1934; 37: 29-38. [http://dx.doi.org/10.1097/00010694-193401000-00003]

[33] Jackson M. Soil Chemical Analysis. Engle Wood Cliffs, New Jersey: Prentice Hall Inc. 1958.

[34] Olsen SR, Cole CV, Watanabe FS, Dean LA. Estimation of available phosphorus in soils by extraction with sodium carbonate. USDA Circular 1954; 939: 1-19.

[35] CIMMYT. From Agronomic Data to Farmer Recommendations: An Economics Training Manual. Completely revised edition. 1988, Mexico. D.F.

[36] Tadesse T. Soil, plant, water, fertilizer, animal manure and compost analysis. International Livestock Research Center for Africa, Working Document No. 13;1991, Addis Ababa.

[37] Hazelton P, Murphy B. Interpreting soil test results: what do all the numbers mean?. Collingwood, VIC, Australia: CSIRO PUBLISHING 2007; p. 152.

[38] Bashour II. Beirut, Lebanon: FAO Report to Ministry of Agriculture 2001; p. Fertility and Fertilizer Requirements. Pp116 In: In Rural Integrated Development of the Mountains of Northern Lebanon. 116.

[39] Morris ML, Kelly VA, Kopicki RJ, Byerlee D. Fertilizer Use in African Agriculture: Lessons Learned and Good Practice Guidelines. Washington, D.C.: World Bank 2007. [http://dx.doi.org/10.1596/978-0-8213-6880-0]

[40] Admasu M. Environment and Social Assessment. Fertilizer Support Project. The Federal Democratic Republic of Ethiopia, Ministry of Agricultural and Rural Development.74p

[41] Zelleke G, Agegnehu G, Abera D, Rashid S. Fertilizer and Soil Fertility Potential in Ethiopia: Constraints and Opportunities for Enhancing the System. Working Paper, International Food Policy Research Institute 2010; 42.

[42] FAO (Food and Agriculture Organization). Plant nutrition for food security: A guide for integrated nutrient management. In: FAO, Fertilizer and Plant Nutrition Bulletin 16, Rome. 2006.

[43] Eastin JD, Haskins FA, Sullivan CY, Van Bavel CHM, Eds. Physiological Aspects of Crop yields American Society of Agronomy. Madison, USA: Crop Society of America 1969; pp. 253-9.

[44] Kumar H, Singh JV, Ajay K, Mahak S, Kumar A, Singh M. Studies on the influence of nitrogen on growth and yield of onion Cv. Patna Red Indian J Agric Res 1998; 32: 88-92.

[45] Bungard RA, Wingler A, Morton JD, Andrews M. Ammonium can stimulate nitrate and nitrite reductase in the absence of nitrate in Clematis vitalba. Plant Cell Environ 1999; 22: 859-66. [http://dx.doi.org/10.1046/j.1365-3040.1999.00456.x]

[46] Al-Fraihat H, Ahmad H. Effect of different nitrogen and sulphur fertilizer levels on growth, yield and quality of onion (Allium cepa L.). Jordan J of Agri Sci 2009; 5(2): 155-65.

[47] Farooqui MA, Naruka IS, Rathore SS, Singh PP, Shaktawat RPS. Effect of nitrogen and sulphur levels on growth and yield of garlic (Allium sativum L.). In: As J Food Ag-Ind. 2009; pp. S18-23. Special Issue

[48] Bagali AN, Patil HB, Chimmad VP, Patil PL, Patil RV. Effect of inorganics and organics on growth and yield of onion (Allium cepa L.). Karnataka J Agric Sci 2012; 25(1): 112-5.

[49] Sharangi AB, Sahu PK. Effect of Placement and Dose of Phosphatic Fertilizers on Onion. J Plant Nutr 2009; 32 (11): 1901-13. [http://dx.doi.org/10.1080/01904160903242383]

[50] Shaheen A, Fatma M, Rizk A, Singer SM. Growing Onion Plants without Chemical Fertilization. Res J Agric Biol Sci 2007; 3(2): 95-104.

[51] Abdu El-Samad EH, Kh R, Khalifa M, Lashine ZA, Shafeek MR. Influence of urea fertilization and foliar application of some micronutrients on growth, yield and bulb quality of onion. Aust J Basic Appl Sci 2011; 5(5): 96-103.

[52] Rezaei EE, Kafi M, Bannayan M. Nitrogen and Cultivated Bulb Weight Effects on Radiation and Nitrogen-Use Efficiency, Carbon Partitioning and Production of Persian Shallot (Allium altissimum Regel.). J Crop Sci Biotechnol 2013; 16(3): $237-44$. [http://dx.doi.org/10.1007/s12892-013-0076-8] 
[53] Steer BT. The Bulbing response to day length and temperature of some Australian cultivars of onion (Allium cepa L.). Aust J Agric Res 1980; 31: $511-8$. [http://dx.doi.org/10.1071/AR9800511]

[54] Nasreen S, Haque MM, Hossain MA, Farid ATM. Nutrient uptake and yield of onion as influenced by nitrogen and sulphur fertilization. Bangladesh J Agric Res 2007; 32(3): 413-20.

[55] Mozumder SN, Moniruzzaman M, Halim MAG. Effect of N, K and S on the Yield and Storability of Transplanted Onion (Allium cepa L.) in the Hilly Region. J Agric Rural Dev 2007; 5(1\&2): 58-63.

[56] Soleymani A, Hesam M. Effects of different levels of nitrogen on yield and nitrate content of four spring onion genotypes. Int J Agric Crop Sci 2012; 4(4): 179-82.

[57] Yadav RL, Sen NL, Yadav BL. Response of onion to nitrogen and potassium fertilization under semi-arid condition. Indian J Hortic 2003; 60(2): 176-8.

[58] Reddy KC, Reddy KM. Differential levels of vermicompost and nitrogen on growth and yield in onion (Allium cepa L.), radish (Raphanus sativus L.) cropping system. J Res ANGRAU 2005; 33: 11-7.

[59] Aliyu U, Magaji MD, Singh A, Mohammed SG. Growth and Yield of Onion (Allium cepa L.) as Influenced by Nitrogen and Phosphorus Levels. Int J Agric Res 2007; 2: 937-44. [http://dx.doi.org/10.3923/ijar.2007.937.944]

[60] Kebede W, Gretsson U, Ascard J. Response of Shallots to mulching and nitrogen fertilization. Hort Sci 2003; 38(2): 1-5. b

[61] Ghaffoor A, Jilani MS, Khaliq G, Waseem K. Effect of different NPK levels on the growth and Yield of Three onion (Allium cepa L.) Varieties. Asian J Plant Sci 2003; 2(3): 342-6. [http://dx.doi.org/10.3923/ajps.2003.342.346]

[62] Singh SP, Mohanty CR. A note on the effect of nitrogen and potassium on the growth and yield of onion. Orissa J Horti 1998; 26 : 70-1.

[63] Lemma D, Yayeh Z, Herath E, Getachew T, Asfaw G. Proceeding of the Second National Horticultural Workshop of Ethiopia, Variety development on vegetables. Addis Ababa. 1994; pp. 276-87.

[64] Rashid MT, Salim M. Effect of soil nitrate nitrogen status on wheat response to applied nitrogen. Pakistan J Soil Sci 1991; 6: 5-7.

[65] Charbaji T, Arabi MIE, Jawhar M. Urea Foliar Fertilization Affects Onion Weight and Nutrient Content. Int J Veg Sci 2008 ; $14(3)$ : $198-204$. [http://dx.doi.org/10.1080/19315260802164285]

[66] Anwar MN, Sarker JU, Rahman M, Islam MA, Begum M. Response of onion to nitrogen, phosphorus, potassium, sulphur and zinc. Bangladesh J Environ Sci 2001; 7: 68-72.

\section{(C) 2018 Tekeste et al.}

This is an open access article distributed under the terms of the Creative Commons Attribution 4.0 International Public License (CC-BY 4.0), a copy of which is available at: (https://creativecommons.org/licenses/by/4.0/legalcode). This license permits unrestricted use, distribution, and reproduction in any medium, provided the original author and source are credited. 